\title{
Electricity production by a microbial fuel cell fueled by brewery wastewater and the factors in its membrane deterioration
}

\author{
Afşin Y. Çetinkaya a,*, Emre Oğuz Köroğlu ${ }^{a}$, Neslihan Manav Demir ${ }^{a}$, Derya Yılmaz Baysoy ${ }^{b}$, \\ Bestamin Özkaya a,c, Mehmet Çakmakçı ${ }^{\text {a }}$ \\ a Department of Environmental Engineering, Yildiz Technical University, Istanbul, Turkey \\ b Department of Physics, Yildiz Technical University, Istanbul, Turkey \\ c Department of Chemistry and Bioengineering, Tampere University of Technology, Tampere, Finland
}

\section{A R T I C L E I N F O}

Article history:

Received 29 December 2014

Accepted 29 February 2015

Published 20 July 2015

\section{Keywords:}

Biofilm

Wastewater treatment

Anaerobic processe

Microbial fuel cell

Microbial community

\begin{abstract}
A B S T R A C T
Electricity production from brewery wastewater using dual-chamber microbial fuel cells (MFCs) with a tin-coated copper mesh in the anode was investigated by changing the hydraulic retention time (HRT). The MFCs were fed with wastewater samples from the inlet (inflow, MFC-1) and outlet (outflow, MFC-2) of an anaerobic digester of a brewery wastewater treatment plant. Both chemical oxygen demand removal and current density were improved by decreasing HRT. The best MFC performance was with an HRT of $0.5 \mathrm{~d}$. The maximum power densities of 8.001 and $1.843 \mu \mathrm{W} / \mathrm{cm}^{2}$ were obtained from reactors MFC- 1 and MFC-2, respectively. Microbial diversity at different conditions was studied using PCR-DGGE profiling of $16 S$ rRNA fragments of the microorganisms from the biofilm on the anode electrode. The MFC reactor had mainly Geobacter, Shewanella, and Clostridium species, and some bacteria were easily washed out at lower HRTs. The fouling characteristics of the MFC Nafion membrane and the resulting degradation of MFC performance were examined. The ion exchange capacity, conductivity, and diffusivity of the membrane decreased significantly after fouling. The morphology of the Nafion membrane and MFC degradation were studied using scanning electron microscopy and attenuated total reflection-Fourier transform infrared spectroscopy.
\end{abstract}

(C) 2015, Dalian Institute of Chemical Physics, Chinese Academy of Sciences. Published by Elsevier B.V. All rights reserved.

\section{Introduction}

Present global energy requirements are mostly dependent on fossil fuels, which are predicted to be depleted because of limited fossil energy sources. The combustion of fossil fuels also has serious negative effects on the environment due to $\mathrm{CO}_{2}$ emission. Climate change, increased global demand for limited oil and natural gas reserves, and energy security have motivated the search for alternatives to fossil fuels [1]. A microbial fuel cell (MFC) is a device to treat wastewater and produce electricity. Microbes attached to the anode of the MFC oxidize substrates such as brewery wastewater and generate electrons and protons in the process. A MFC is a bioelectrochemical system that exploits the bacterial oxidation of biodegradable organic matter to generate electricity [2-4]. The microbial metabolism generates electrons $\left(\mathrm{e}^{-}\right)$and protons $\left(\mathrm{H}^{+}\right)$by the oxidation of organic substrates, which produces a biopotential. The electrons are transferred to the anode by the bacteria by several mechanisms, such as by a solid transfer matrix or electron shuttling. Electrons are then transferred to the cathode through an external circuit [5]. Brewery wastewater produced in cooling and washing units has a high chemical oxygen de-

\footnotetext{
* Corresponding author. Tel: +90-2123835402; Fax: +91-2123835102; E-mail: afsinyc@yildiz.edu.tr, afsincetinkaya@gmail.com This work was supported by Scientific Research Project Coordination of Yildiz Technical University (2012-05-02-KAP06). 


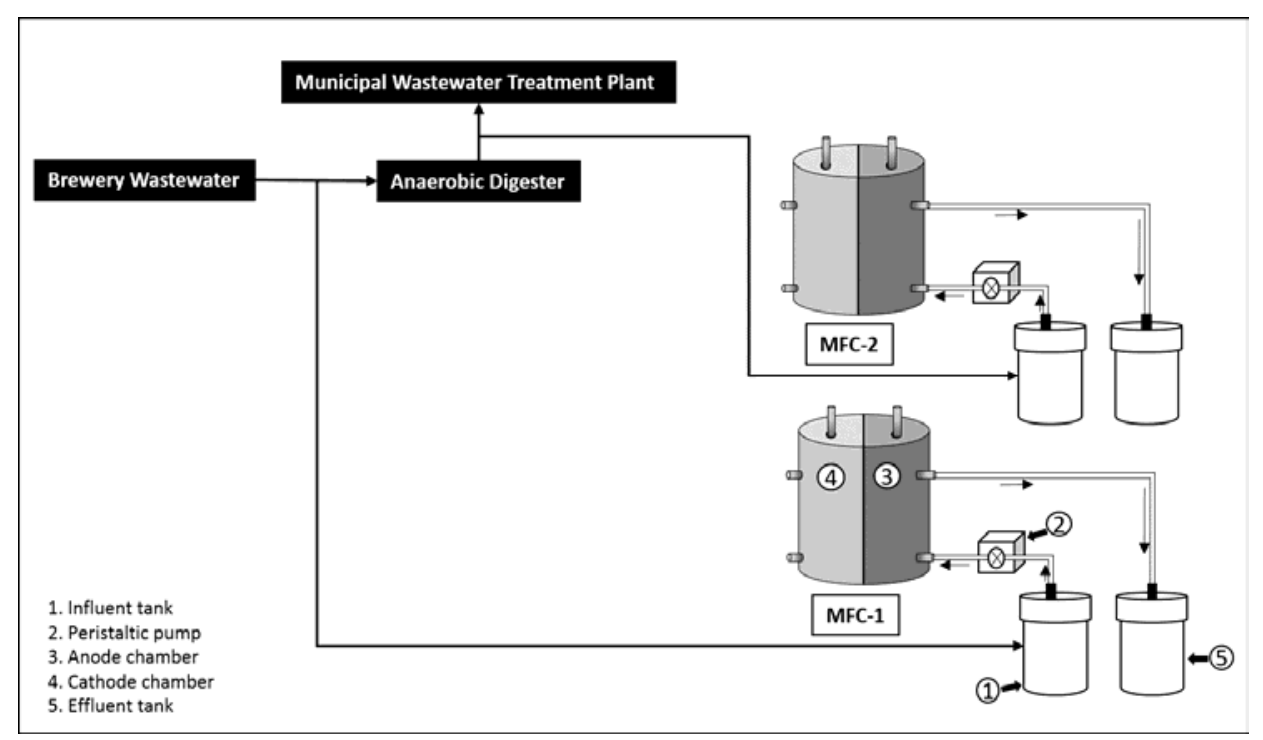

Fig. 1. Schematic of the brewery wastewater treatment plant and MFCs.

mand (COD) but is nontoxic. There are electrochemical limitations on the performance of the MFCs because of the discharge resistance, which results from ohmic, kinetic, and transport limitations [6,7]. A reverse correlation exists between the discharge resistance and power output $[8,9]$. Electrochemical impedance spectroscopy (EIS) is a technique that measures the resistance of a fuel cell [10]. There has been some research on resistance analysis by EIS using simulated artificial wastewater [11]. However, there are few reports using real wastewater.

In this paper, the possibility of continuous electricity production from brewery wastewater using dual-chamber MFCs was studied. The influences of the hydraulic retention time (HRT) on the voltage and power density and the effect of COD removal efficiency on the MFC performance were investigated. A basic electrochemical model of the MFC was set up using the polarization curve, and an elaborate analysis of the various voltage losses was conducted to obtain the net fuel cell $J-V$ behavior. The surface morphology, dispersion, and functional groups were investigated by scanning electronic microscopy (SEM) and attenuated total reflection-Fourier transform infrared (ATR-FTIR) spectroscopy.

\section{Experimental}

\subsection{MFC construction and operation}

Two identical plexiglass dual-chamber MFCs were constructed on the basis of a previous study $[12,13]$. The reactors comprised a Nafion ${ }^{\circledR} 117$ (Dupont) proton exchange membrane (PEM) to separate the partitions and tin-coated copper mesh as the anode and cathode electrodes. The PEM and tin-coated copper mesh had an effective area of $7 \mathrm{~cm}^{2}$ and were fixed in the middle of the two chambers. The volumes of the anode and cathode chambers were $275 \mathrm{~cm}^{3}$, and the effective volumes were $250 \mathrm{~cm}^{3}$. Nafion ${ }^{\circledR} 117$ was sequentially pretreated at $85{ }^{\circ} \mathrm{C}$ for $1 \mathrm{~h}$ in $5 \% \mathrm{H}_{2} \mathrm{O}_{2}$, distilled water, $0.05 \mathrm{~mol} / \mathrm{L}$ $\mathrm{H}_{2} \mathrm{SO}_{4}$, and distilled water as described in the literature [7]. The electrodes were in contact with the PEM and the outer surface of the cathode was exposed to distilled water. The electrodes were connected by a titanium wire across a decade resistance box with $500 \Omega$ external resistance at start-up and $100 \Omega$ thereafter, except during the power density and EIS analysis. The MFCs were fed with wastewater samples obtained from the inlet (called the inflow (MFC-1)) and outlet (called the outflow (MFC-2)) of the anaerobic digester of a brewery wastewater treatment plant (Fig. 1). Brewery wastewater was collected from a local brewing plant in Istanbul, which produces malt from barley. The characteristics of the two types of wastewater are given in Table 1.

The MFCs were continuously operated at room temperature $\left(25 \pm 2{ }^{\circ} \mathrm{C}\right)$ for approximately $87 \mathrm{~d}$. $\mathrm{N}_{2}$ was sparged to maintain anaerobic conditions in the anodic chamber. The wastewater in the MFC reactors was initially inoculated with a sediment sample obtained from the Golden Horn in Istanbul at a ratio of 1:10. The enrichment of microorganisms was carried out using a 250-mL serum bottle under anaerobic conditions. The enrichment medium was a composition of synthetic wastewater constituents with the following compounds (amount in $1 \mathrm{~L}$ deionized water): $9 \mathrm{~g}$ glucose, $4 \mathrm{~g}$ yeast extract, 4 g NaHCO $3,0.6 \mathrm{~g} \mathrm{NH}_{4} \mathrm{Cl}, 9.3 \mathrm{~g} \mathrm{NaH}_{2} \mathrm{PO}_{4} \cdot \mathrm{H}_{2} \mathrm{O}, 3.2 \mathrm{~g} \mathrm{Na}_{2} \mathrm{H}_{2} \mathrm{PO}_{4}$, $0.125 \mathrm{~g} \mathrm{~K}_{2} \mathrm{HPO}_{4} \cdot 3 \mathrm{H}_{2} \mathrm{O}, 0.1 \mathrm{~g} \mathrm{MgCl}_{2} \cdot 6 \mathrm{H}_{2} \mathrm{O}, 0.11 \mathrm{~g} \mathrm{CaCl}_{2} \cdot 2 \mathrm{H}_{2} \mathrm{O}$, $3.92 \mathrm{~g} \mathrm{NaHCO}_{3}$, and trace amounts of metal ions (Fe, $\mathrm{Zn}, \mathrm{Co}, \mathrm{Cu}$, and $\mathrm{Ni}$ ) and vitamins [14]. The $\mathrm{pH}$ of the medium was 6.7. Cysteine $(0.5 \mathrm{~g} / \mathrm{L})$ was included in order to keep the medium in an anaerobic condition. The medium $(100 \mathrm{~mL})$ was put into the bottle and flushed with nitrogen gas for $5 \mathrm{~min}$ to remove the air inside. Then the bottle was capped with a rubber stopper and stirred at $150 \mathrm{rpm}$ with a magnetic stirrer. Each enrichment

Table 1

Characteristics of the brewery wastewater.

\begin{tabular}{lcccc}
\hline Stage & COD $(\mathrm{mg} / \mathrm{L})$ & BOD $_{5}(\mathrm{mg} / \mathrm{L})$ & TN $(\mathrm{mg} / \mathrm{L})$ & $\mathrm{TP}(\mathrm{mg} / \mathrm{L})$ \\
\hline MFC-1 & $2250 \pm 80$ & $650 \pm 50$ & $35 \pm 2$ & $33 \pm 2$ \\
MFC-2 & $480 \pm 20$ & $250 \pm 20$ & $10 \pm 2$ & $12 \pm 4$ \\
\hline
\end{tabular}


cycle continued for $2 \mathrm{~d}$ at room temperature $\left(25^{\circ} \mathrm{C}\right)$. After the second transfer, the enriched culture was inoculated into the anode chamber. As discussed in previous studies, the external resistance in the MFCs affected bacterial diversity and intermediate metabolism [1]. Therefore, the anode was enriched with a $500 \Omega$ external resistance. After $5 \mathrm{~d}$, the anode solution was removed and replaced with fresh wastewater, and the external resistance was gradually decreased to $100 \Omega$. The cathode chamber was filled with distilled water and aerated continuously at $10 \mathrm{~cm}^{3} / \mathrm{min}$ at $20{ }^{\circ} \mathrm{C}$ and $101 \mathrm{kPa}$. The MFC reactors were operated in continuous mode. They were fed by a peristaltic pump (Watson Marlow, Belgium) and refilled every time the OCV dropped below $200 \mathrm{mV}$.

\subsection{Analysis}

The voltage $(V)$ across the load was monitored at 5 min intervals in real time using a computer-based data logging system (Agilent 34970A). The current $(I)$ and power $(P=I V)$ were calculated as described in a previous study [7] and normalized to the effective surface area of the anode $\left(7 \mathrm{~cm}^{2}\right)$. MFC performance was analyzed by EIS using the Ludre $\mathrm{L}_{02} / \mathrm{V}_{01}$ software (produced by Ludre Software, Istanbul, Turkey) electrochemical interface connected to a computer equipped with ZsimpWin 3.22 software [7,15]. Polarization and power density curves were obtained automatically for the range of external resistance of 10-20 k $\Omega$. The current and potential were normalized to the effective surface area of the electrode $\left(7 \mathrm{~cm}^{2}\right)$.

EIS was performed over the frequency range of $1 \mathrm{mHz}$ to $100 \mathrm{kHz}$. The amplitude of the modulating sinusoidal voltage was $10 \mathrm{mV}$ using a Ludre potentiostat. By fitting and simulating the experimental data with equivalent circuits, the internal resistance distributions were calculated using ZsimpWin 3.22. All chemical analyses were done using the standard APHAAWWA-WEF methods [16]. Microstructural changes in the Nafion were determined using the attenuated total reflection (ATR) method with an IR spectrometer with a Watson 1000 FTIR apparatus. Spectra were acquired using 100 scans between 400 and $4000 \mathrm{~cm}^{-1}$ at a resolution of $16 \mathrm{~cm}^{-1}$. A CamScan Apollo-300 scanning electron microscope (SEM) with energy dispersive X-ray analysis (EDX) was used to investigate the membrane morphology. The film surface was sputter coated with gold (Polaron Range). SEM pictures were taken at $2000 \times$ magnification.

\subsection{Microbial community analysis}

The diversity and changes in the bacterial population of the inflow and outflow were profiled by DNA extraction and the PCR-DGGE of partial $16 S$ rRNA genes followed by their sequencing. The extraction of DNA from the samples was performed using a PowerSoil DNA isolation kit (MO BIO Laboratories, Inc., USA) using the manufacturer's instructions. Universal GC-BacV3f (5'-CGC CCG CCG CGC GCG GCG GGC GGG GCG GGG GCA CGG GGG GCC TAC GGG AGG CAG CAG-3') and 907R (5'-CCG TCA ATT CMT TTG AGT TT-3') primers were used for amplifying the bacterial $16 S$ rRNA genes for DGGE analysis $[1,17,18]$.
Each PCR reaction mixture was prepared with a total volume of $50 \mu \mathrm{L}$ containing $2 \mu \mathrm{L}$ of each DNA extract to $0.25 \mu \mathrm{L}$ of $100 \mu \mathrm{mol} / \mathrm{L}$ primers, $5 \mu \mathrm{L}$ combination of $10 \times$ reaction buffer (TriseHCl, pH 8.8), $0.125 \mu \mathrm{L}$ of $40 \mathrm{mmol} / \mathrm{L}$ dNTPs, $0.75 \mu \mathrm{L}$ Taq DNA polymerase, $1 \mu \mathrm{L}$ bovine serum albumin, and $40.63 \mu \mathrm{L}$ sterile purified water. The PCR amplification of $16 S$ rRNA was performed with a BIO-RAD Mycycler Thermal Cycler System using the protocol: initial denaturation at $95^{\circ} \mathrm{C}$ for $5 \mathrm{~min}$, followed by 30 cycles of denaturing at $94^{\circ} \mathrm{C}$ for $0.5 \mathrm{~min}$, annealing at $50{ }^{\circ} \mathrm{C}$ for $1 \mathrm{~min}$ and extension at $72{ }^{\circ} \mathrm{C}$ for $2 \mathrm{~min}$, and the final extension at $72{ }^{\circ} \mathrm{C}$ for $10 \mathrm{~min}$ and end at $4{ }^{\circ} \mathrm{C}$.

The DGGE profiling of bacterial populations was performed using a Bio-Rad Dcode system (Bio-Rad, USA). Electrophoresis was carried out in $8 \%$ acrylamide gels with a denaturing gradient from $25 \%$ to $65 \%$ (7 mol/L urea plus $40 \%$ formamide). Gels were run at $60{ }^{\circ} \mathrm{C}$ and $60 \mathrm{~V}$ for $30 \mathrm{~min}$, and at $120 \mathrm{~V}$ for $8 \mathrm{~h}$, then stained with SYBRs Gold and the bands were observed under blue light. The dominant bands were eluted using sterile water overnight. The sequences were compared with the data in GenBank (http://www.ncbi.nlm.nih.gov/blast/).

\section{Results and discussion}

\subsection{Polarization measurements}

The HRT is an important parameter in wastewater treatment and it directly affects the design and operation of the equipment. Research has shown that the HRT has a significant effect on the electricity production characteristics of a continuousflow MFC [19]. The type and quantity of bacteria can be controlled by regulating the HRT. When the HRT is decreased, the strength of the substrate is increased, resulting in an increase in the total rate of substrate consumption (by bacteria), and power generation will increase [10]. To understand the effects of the HRT on the power output, MFC- 1 and MFC- 2 were operated continuously at three different HRTs $(0.5,0.75$, and 1 d).

Fig. 2 illustrates the results of the effect of HRT on polarization diagram and power density. At high HRT, there was a rapid drop in voltage, which was followed by a linear decrease. The ideal polarization curve can be divided into three regions: activation polarization at high current density, concentration polarization at low current density, and ohmic polarization in the intermediate linear region. In this study, the internal resistance was determined from the sum of all the resistances obtained from the simulation results. Fig. 2(a) shows that a maximum power density of $8.001 \mu \mathrm{W} / \mathrm{cm}^{2}$ was produced from MFC-1 at an HRT of $0.5 \mathrm{~d}$ with $100 \Omega$ external resistance and $79.58 \Omega$ internal resistance. The stepwise increase of HRT from 0.5 to 1 $\mathrm{d}$ gave a smaller power output relative to that at $0.5 \mathrm{~d}$. The power density was decreased to $1.069 \mu \mathrm{W} / \mathrm{cm}^{2}$ by increasing HRT to $1 \mathrm{~d}$ for MFC-1.

For MFC-2, the maximum power density was not negatively affected by increasing the HRT. The power decreased from 1.843 to $1.235 \mu \mathrm{W} / \mathrm{cm}^{2}$ as a result of changing HRT from 0.5 to $0.75 \mathrm{~d}$ and it increased again to $1.731 \mu \mathrm{W} / \mathrm{cm}^{2}$ for the HRT of 1 d. The internal resistance was increased from 10.59 to 200.15 

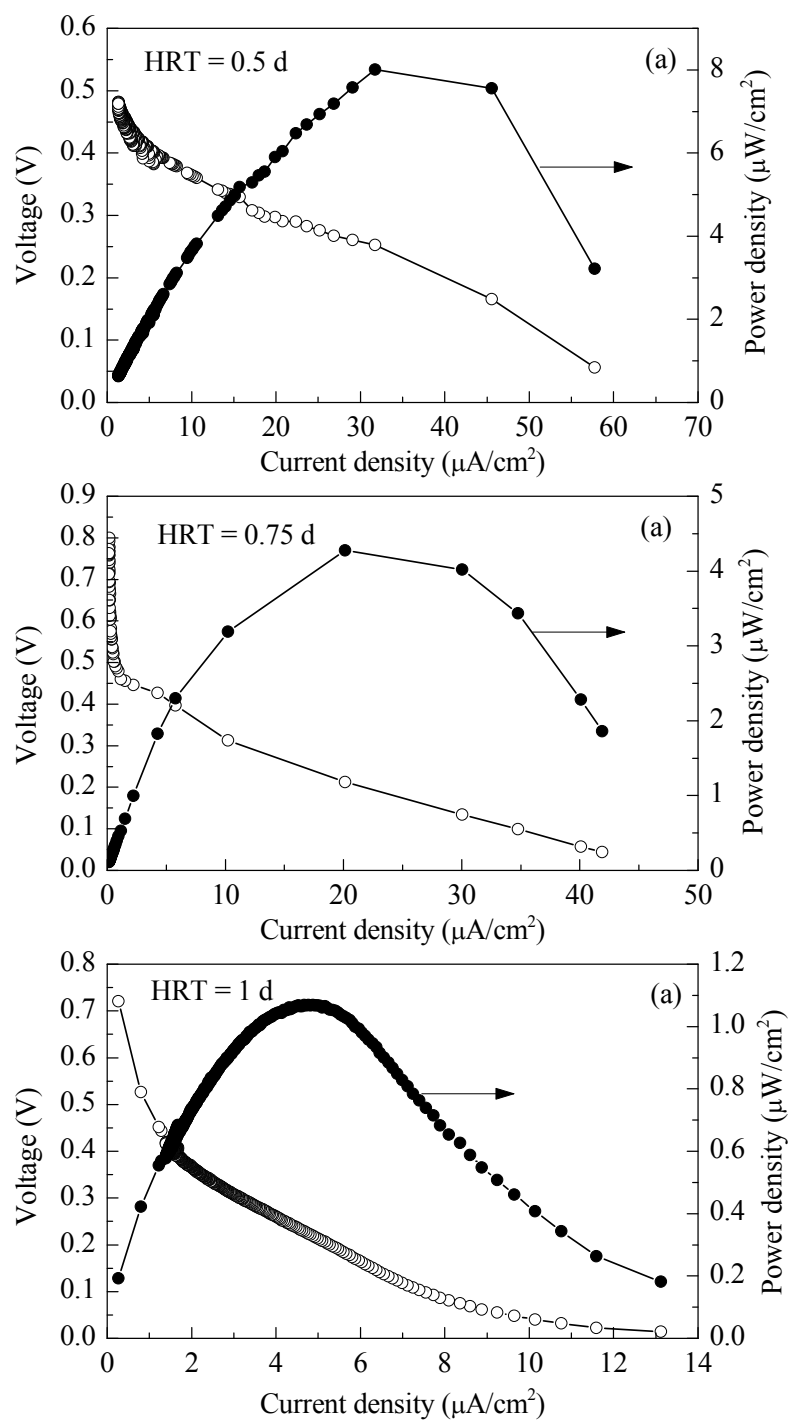
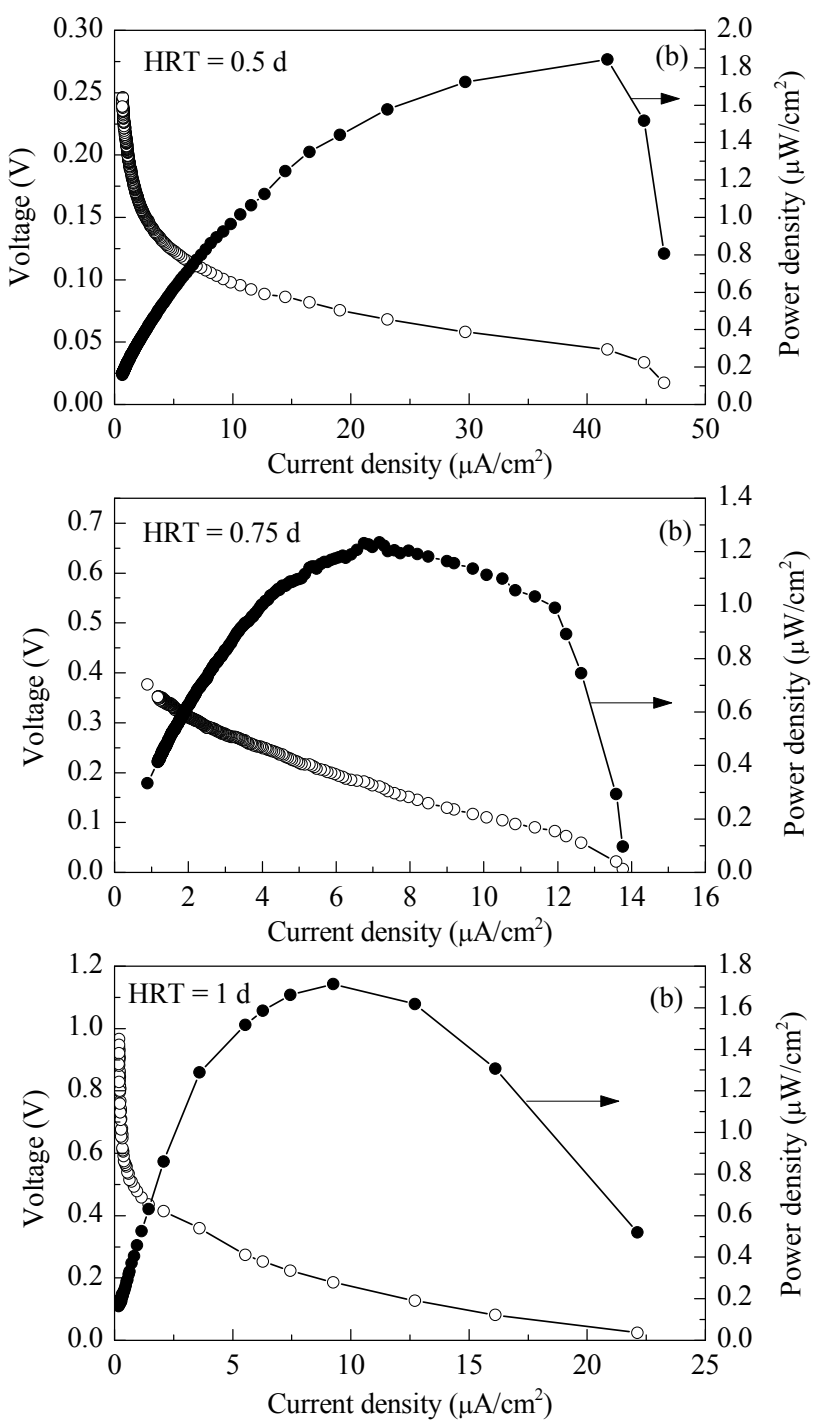

Fig. 2. Polarization and power density curves for MFC-1 (a) and MFC-2 (b) at different HRTs.

$\Omega$ by increasing the HRT. A similar power output from the HRT values of 1 and $0.5 \mathrm{~d}$ could be explained by the internal resistance. However, a sustainable and higher power output was obtained from MFC-2 when the external resistance was close to the internal resistance.

The results demonstrated that the performance of MFC-1 was better than that of MFC-2 as a consequence of the organic loading rates. The internal resistance results also showed a good relationship with the external resistance. There was sustainable power output from the MFCs. The higher power output obtained at low HRTs confirmed that a continuous supply of brewery wastewater was rapidly converted to energy.

\subsection{Electrochemical impedance spectroscopy}

Electrochemical impedance spectroscopy measurements were performed for MFC-1 and MFC-2 at the optimum HRT of $0.5 \mathrm{~d}$ using a potentiostat (Ludre Software, Istanbul, Turkey). The Nyquist impedance plots for both MFCs are shown in Fig. 3.

Performance parameters such as the solution resistance $\left(R_{\mathrm{s}}\right.$, ohmic resistance), anodic $\left(R_{\mathrm{a}}\right)$ and cathodic $\left(R_{\mathrm{c}}\right)$ polarization resistances, and constant phase element (CPE) were determined by fitting the impedance data to an equivalent circuit of the system, which is shown in Fig. 4. The equivalent circuit was defined using the best fit for the EIS data. Observed differences

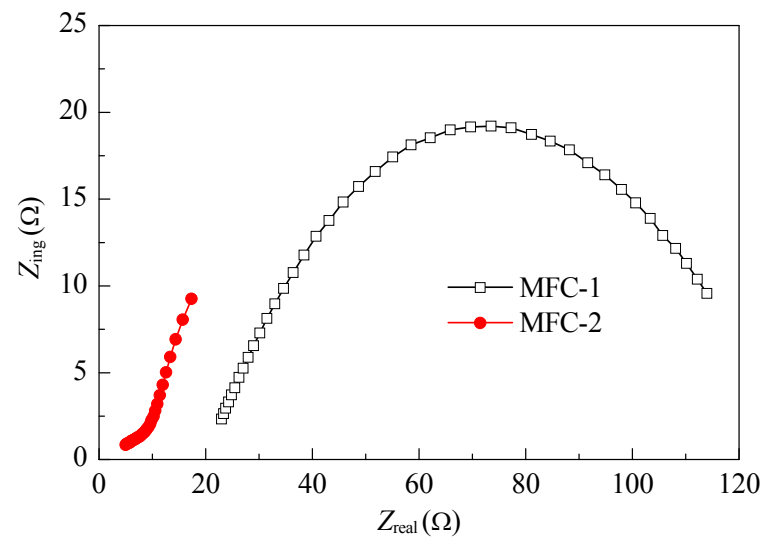

Fig. 3. Nyquist plots for MFC-1 and MFC-2. 


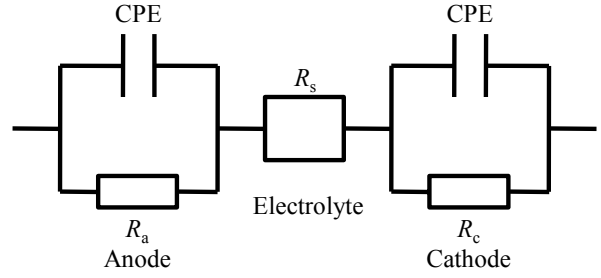

Fig. 4. Equivalent circuit for the two MFCs.

in the values of $R_{\mathrm{s}}, R_{\mathrm{a}}$, and $R_{\mathrm{c}}$ are given in Table 2 .

Variations in the composition and concentration of the ions in the electrolytes changed the resistance of the solution, thus causing ohmic losses in the MFCs during the operation with an HRT of $0.5 \mathrm{~d}$. As seen in Table 2, $R_{\mathrm{c}}$ (inverse of the cathodic reaction rate), $R_{\mathrm{s}}$, and $R_{\mathrm{a}}$ were higher in MFC-1 compared to MFC-2. The reasons for this were the different wastewater compositions and the concentrations of the ions in the wastewater.

The internal resistance was determined from the sum of all the resistances obtained from the simulation results. The main resistance was found to be the anodic charge transfer resistance $(50 \%$ and $62.4 \%$ in MFC- 1 and MFC-2, respectively) which was inversely proportional to the chemical reaction rate in all runs. In this study, the reactors were inoculated with a mixed culture. However, it has been suggested that the use of more active microorganisms will decrease the anodic charge transfer resistance [20].

\subsection{Experimental results}

The average TN removal was similar for both MFCs: $47 \%$ for MFC- 1 and $41 \%$ for MFC-2, while the TP removal efficiencies were $65 \%$ and $55 \%$, respectively. After stabilization, the highest COD removal efficiency was $82 \%$ in both systems. This was because readily available organics were supplied to the MFCs in sufficient quantity and were rapidly converted to electricity by the anode biofilm with the increase of the influent concentration. This result is in agreement with previous findings that the anodic reactions are determined by the available carbon fuel in the influent COD [21]

\subsection{Changes in microbial population}

The changes in the DGGE profile of the microbial population in the MFCs are presented in Fig. 5. The closest relatives of each band are given in Table 3. The first two lanes represent the microbial diversity in the influent brewery wastewater, while the last two show the bacterial population in the effluent brewery wastewater. Uncultured Clostridium sp. (band 8) was only present in the inflow brewery wastewater. Similarly, uncultured Firmicutes bacterium (band 4) was present only in the

Table 2

Impedance parameters of MFC- 1 and MFC- 2 .

\begin{tabular}{lcccc}
\hline Stage & $R_{\mathrm{a}} / \Omega$ & $R_{\mathrm{c}} / \Omega$ & $R_{\mathrm{s}} / \Omega$ & $R_{\text {in }} / \Omega$ \\
\hline MFC-1 & $65(50 \%)$ & $45(34.6 \%)$ & $20(15.4 \%)$ & 130 \\
MFC-2 & $28.26(62.4 \%)$ & $15(33.2 \%)$ & $2(4.4 \%)$ & 45.26 \\
\hline
\end{tabular}

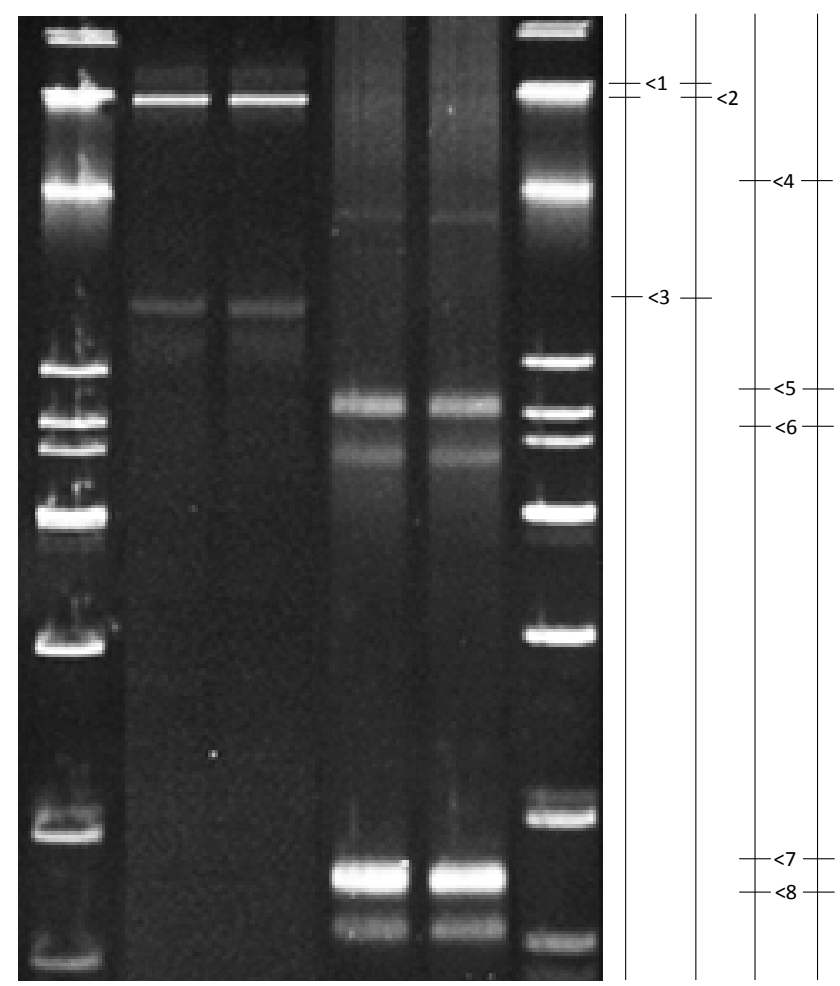

Fig. 5. DGGE profile of the bacterial diversity in brewery wastewater.

outflow brewery wastewater. Uncultured Geobacter sp. (bands 2 and 7) was identified in the MFC reactors operated with both influent and effluent brewery wastewater.

Uncultured Geobacter sp. was dominant in both MFC reactors. Uncultured bacterium sp. (bands 1, 3, 5, and 6) also played an important role in the treatment of brewery wastewater by the MFC reactors [22,23].

The distribution of the bacterial population indicated that MFC-1 and MFC-2 were dominated by Geobacter and Clostridium species. Clostridium, Geobacter, Firmicutes, and Shewanella species have been commonly reported as having the capability to generate electricity [23].

\subsection{Properties of clean Nafion 117 membrane}

ATR-FTIR, SEM and EDX, and TGA/DSC analysis were performed on the clean membranes. The ATR-FTIR spectra of the clean membrane are shown in Fig. 6. The bands in the spectra are given in Table 4 .

\section{Table 3}

Closest relatives of the DGGE bands.

\begin{tabular}{lcccc}
\hline $\begin{array}{l}\text { Band } \\
\text { No. }\end{array}$ & Bacteria & Accesion & Similarity & Ref. \\
\hline 1 & No. & $(\%)$ & \\
2 & Uncultured bacterium & EF515697 & 99 & {$[24]$} \\
3 & Uncultured Geobacter $s p$. & JF817834 & 93 & {$[20]$} \\
4 & Uncultured Firmicutes bacterium & FR823624 & 92 & {$[25]$} \\
5 & Uncultured bacterium & FR823544 & 88 & {$[26]$} \\
6 & Uncultured bacterium & EF515517 & 92 & {$[25]$} \\
7 & Uncultured Geobacter $s p$. & JF817745 & 82 & {$[24]$} \\
8 & Uncultured Clostridium $s p$. & JQ724353 & 93 & {$[27]$} \\
\hline
\end{tabular}



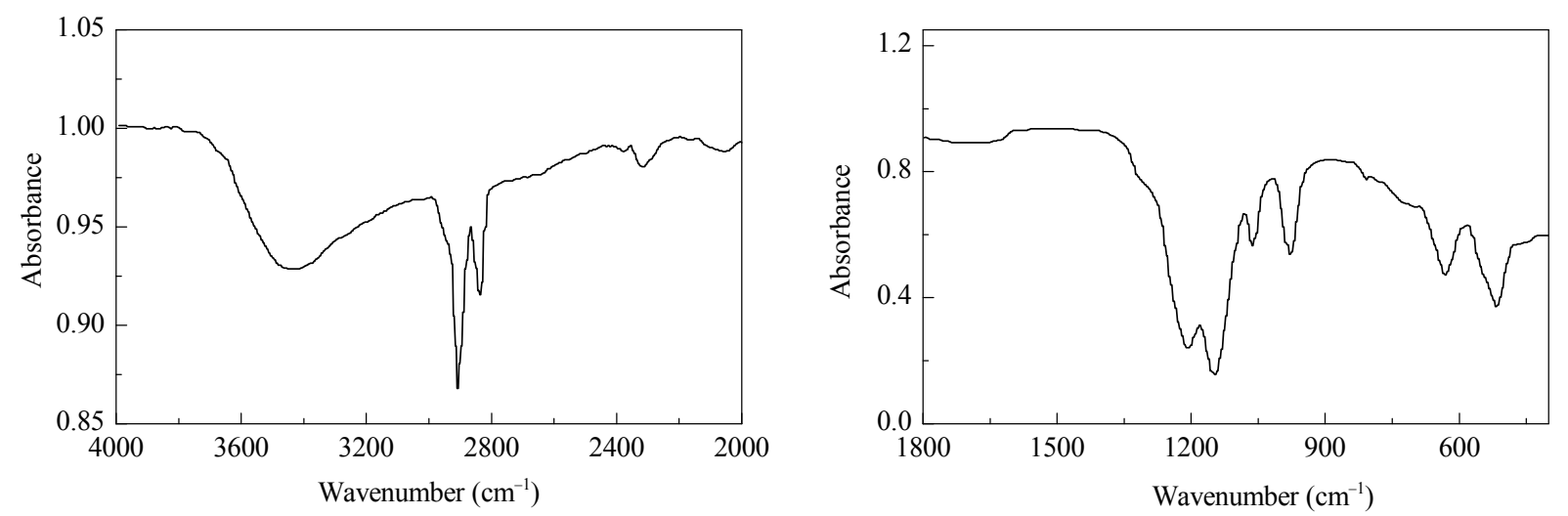

Fig. 6. ATR-FTIR spectra of a clean Nafion 117 membrane.

Two types of water, free and bound, were found in the membrane. Free water is usually shown in the $3700-3080 \mathrm{~cm}^{-1}$ zone as monomeric $\mathrm{H}_{2} \mathrm{O}$ molecules (Fig. 6). Bound water is present in the porous structure and it is difficult to remove [14,35].

This band was directly related to the increase in the hydrophilic and conductive properties of the membrane and corresponded to the stretching of $\mathrm{H}-\mathrm{O}$ in the free $\mathrm{SO}_{3} \mathrm{H}$ group $[16,28]$. In Nafion membranes, the 1410 and $910 \mathrm{~cm}^{-1}$ bands are attributed to the $\mathrm{S}=\mathrm{O}$ and $\mathrm{S}-\mathrm{OH}$ vibrations of the stretching band of $\mathrm{SO}_{3}{ }^{\mathrm{H}}$ [16]. The membrane showed two peaks at 1056 and $1300 \mathrm{~cm}^{-1}$, which were the $-\mathrm{SO}_{3}{ }^{-}$asymmetric and symmetric stretching bands, respectively. The asymmetric $-\mathrm{SO}_{3}$ band can be obscured by strong $\mathrm{C}-\mathrm{F}$ absorption. However, the moisture sensitivity can be affected by proton transfer [16]. In Fig. 6, this band was observed as a shoulder at 1316 and $1304 \mathrm{~cm}^{-1}$, which supported this conclusion. Also, the vibrations of the $-\mathrm{SO}_{3}-$ and $\mathrm{SO}_{3}{ }_{3} \mathrm{H}$ groups gave information about proton transfer, the proton transport mechanism, and coordination events [16]. In Fig. 6, strong peaks of CF bands were observed in the region between 1300 and $1100 \mathrm{~cm}^{-1}$. For the Nafion membrane, two bands appeared in the region between 1000 and $900 \mathrm{~cm}^{-1}$, which are $\mathrm{C}-\mathrm{O}-\mathrm{C}$ bonds directly connected to the main and side chains.

\subsection{Properties of the used membrane}

The MFC-1 and MFC-2 membranes were assessed in two

Table 4

Bands in the ATR-FTIR spectrum of a clean Nafion 117 membrane.

\begin{tabular}{lc}
\hline $\begin{array}{l}\text { Wavenumber } \\
\left.\text { (cm }{ }^{-1}\right)\end{array}$ & Bands \\
\hline 3453 & OH stretching of water molecule [28-30] \\
2713 & $\mathrm{CH}_{2}$ asymmetric aliphatic stretching [30] \\
2379 & $\mathrm{CH}_{3}$ symmetric aliphatic stretching [30] \\
1316 & Asymmetric stretching vibration of sulfone group [31] \\
1199 & $\mathrm{CF}_{2}$ asymmetric stretching [32] \\
1142 & $\mathrm{CF}_{2}$ symmetric stretching [32] \\
1056 & Symmetric stretching vibration of sulfone group [31] \\
979 & $\mathrm{C}-\mathrm{O}-\mathrm{C}$ connected to the main chain [32,33] \\
969 & $\mathrm{C}-\mathrm{O}-\mathrm{C}$ connected to the main chain [32,33] \\
716 & $\mathrm{C}=0$ bending [34] \\
626 & $-\mathrm{SO}_{3}{ }^{-}$in clean Nafion membrane [34]
\end{tabular}

different ways. A comparison of the membranes taken from the reactors is shown in Fig. 7. In Fig. 7, the MFC-2 data are not shown because of the overlap of the signals, but there were some differences in the peaks. The $\mathrm{OH}$ stretching band of the MFC-2 membrane was shifted to the lower frequencies, and the intensity decreased compared with MFC-1. In fuel cell systems, a decrease in the intensity of this band means that the $\mathrm{OH}$ groups on the membrane surface were decreased, and this is directly proportional to a reduction in membrane conductivity [16]. This shift in the band can be due to microbial contamination on the surface of the membrane [28]. The shift amount of the anode was $877 \mathrm{~cm}^{-1}$. This was also referred to as a N-H stretching vibration band (amide band of protein) [16]. In addition, more obviously seen on the anode side, a new peak at $2921 \mathrm{~cm}^{-1}$ was observed. This peak was not present for the cathode. When the $-\mathrm{SO}_{3}{ }^{-}$asymmetric and symmetric stretching bands of MFC- 2 and MFC- 1 membranes are compared, it can be seen that the intensity of these bands was very low for the anode side and it had disappeared for the cathode. Similarly, for both the anode and cathode, the CF symmetric band had disappeared, and the intensity of the asymmetric band was significantly reduced (for the anode at $1212 \mathrm{~cm}^{-1}$ and for the cathode at $1216 \mathrm{~cm}^{-1}$ ). As shown in Fig. 7, the symmetric C-F and $\mathrm{C}-\mathrm{O}-\mathrm{C}$ bands of the sulfone group formed a broad spectrum band $\left(1060 \mathrm{~cm}^{-1}\right)$ in the region between 1181 and $842 \mathrm{~cm}^{-1}$ for the anode. In microbial fuel cells, a visible biofilm forms on the surface of the membrane layer. The analysis showed that the

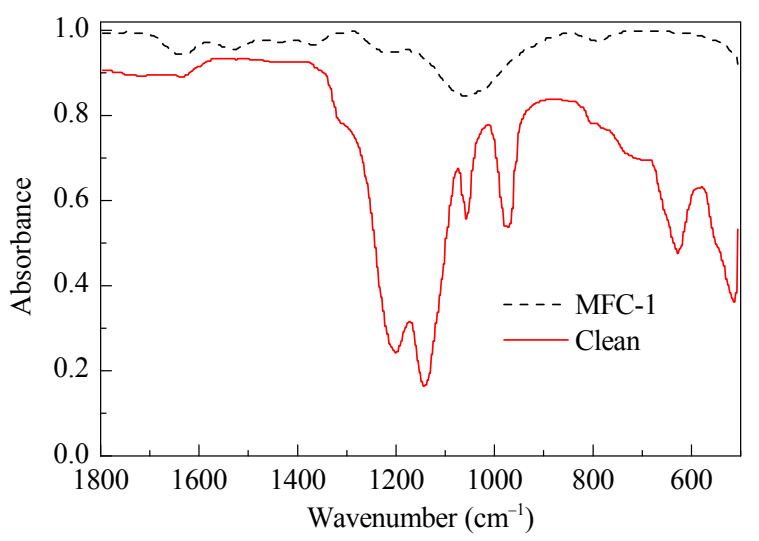

Fig. 7. ATR-FTIR spectra of the membranes. 
biofilm layer comprised organic substances. These substances contain carbon (C), oxygen (O), sulfur (S), thiol (S-H) groups, and disulfide (S-S) groups. In Fig. 7, a sharp peak at $1627 \mathrm{~cm}^{-1}$ was observed, which corresponded to the protein from amide-I [6]. This peak also indicated the contamination of the membrane surface over time.

\subsection{SEM of the membranes}

An SEM image of a clean membrane is shown in Fig. 8(a). The surface of the membrane was smooth and clean. The pores can be observed on close examination.

SEM images taken at different places of the MFC-1 membrane surface are shown in Fig. 8(b,c). When the images of the clean Nafion and MFC-1 membrane surfaces are compared, a physical increase in biocontamination can be observed. After the experimental study in the reactor, it was observed that a biofilm containing $\mathrm{S}$ anions and $\mathrm{Cu}, \mathrm{Fe}$, and $\mathrm{Ca}$ cations was formed. The EDX, ATR-FTIR, and electrical data further supported this.

SEM images taken at different places of the MFC-2 membrane surface are shown in Fig. 8(d,e). When the images of the MFC-2 membrane and the MFC-1 membrane surface (Fig. $8(b, c))$ are compared, a physical increase in biocontamination on the surface of membrane can be observed. After the experimental study in the reactor, it is observed that a biofilm containing Fe and Ca cations has been formed on the surface of the MFC-1 membrane. EDX, ATR-FTIR, and electrical data also supported this.

\subsection{EDX of a clean membrane}

The quantitative data of EDX spectra of a clean membrane are given in Table 5. It can be seen that the membrane is composed of $\mathrm{C}$ and $\mathrm{F}$. Au atoms were also present because the SEM-EDX images were obtained after coating the surface of the membrane with gold. As there were no other elements apart from these three, it can be concluded that the surface was smooth.

The data of EDX spectra of the MFC- 1 membrane are also given in Table 5. A comparison of the clean Nafion membrane and MFC- 1 membrane showed that $\mathrm{Ca}, \mathrm{Na}, \mathrm{Cu}$, and $\mathrm{Fe}$ cations were present on the surface of the membrane. The EDX data of the MFC-2 membrane in Table 5 showed that $\mathrm{Ca}, \mathrm{Mg}$, and $\mathrm{Fe}$ cations were found on the surface of the MFC-2 membrane.

\section{Conclusions}

The effects of the organic loading rate on the MFCs were investigated versus the HRT and COD concentration. Up to an HRT of $0.5 \mathrm{~d}$, COD removal and current density increased. At an HRT of $0.5 \mathrm{~d}$, the highest COD removal efficiency and voltage were $82 \%$ and $0.31 \mathrm{~V}$, respectively. At the HRT of $0.5 \mathrm{~d}$, the maximum power densities of 8.001 and $1.843 \mu \mathrm{W} / \mathrm{cm}^{2}$ were obtained with reactors MFC-1 and MFC-2, respectively. For the MFC-1 reactor, the maximum power density decreased from 8.001 to $1.069 \mu \mathrm{W} / \mathrm{cm}^{2}$ on increasing the HRT from 0.5 to $1 \mathrm{~d}$. The microbial population in the MFC was dominated by Geobacter, Shewanella, and Clostridium species, and some bacteria were easily washed out at lower HRTs. The Nafion membrane became fouled by microorganisms, extracellular polymers, and inorganic salts during the MFC operation, which will disrupt the MFC performance. After fouling of the Nafion membrane, the properties of the membrane were negatively influenced. In addition, physical blockage of cation transfer can also cause the decay of the current.

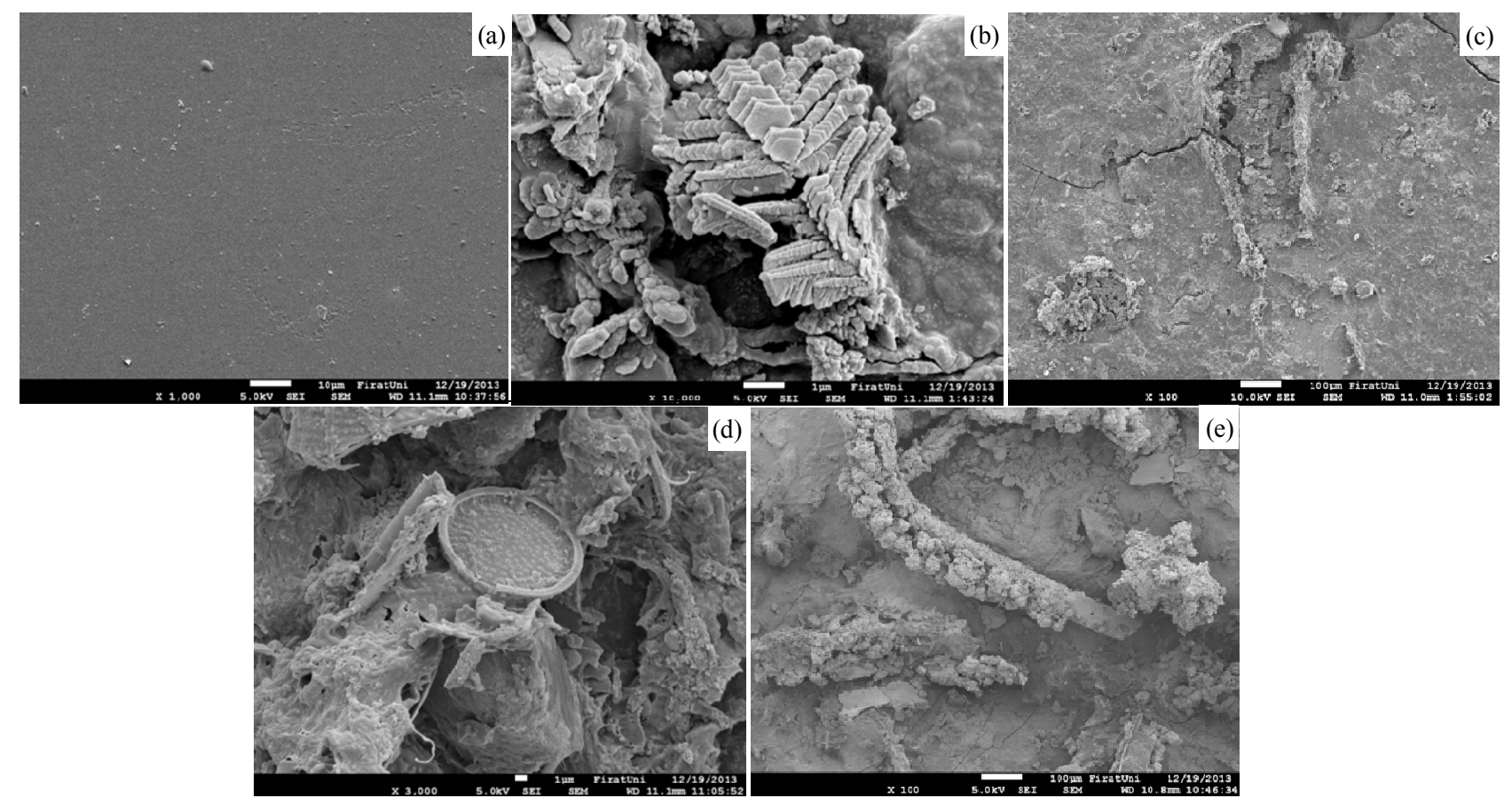

Fig. 8. SEM images of a clean Nafion membrane surface (a), MFC-1 membrane surface (b,c), the MFC-2 membrane surface (d,e). 
Table 5

Quantitative data of the EDX spectra of the clean Nafion membrane, MFC-1 membrane, and MFC-2 membrane.

\begin{tabular}{|c|c|c|c|c|c|c|c|c|c|}
\hline \multirow{2}{*}{ Element } & \multicolumn{3}{|c|}{ Clean Nafion membrane } & \multicolumn{3}{|c|}{ MFC-1 membrane } & \multicolumn{3}{|c|}{ MFC-2 membrane } \\
\hline & Intensity & $\mathrm{Wt} \%$ & At $\%$ & Intensity & $\mathrm{Wt} \%$ & At $\%$ & Intensity & $\mathrm{Wt} \%$ & $\mathrm{At} \%$ \\
\hline $\mathrm{C}$ & 2.0040 & 18.27 & 58.54 & - & - & - & 1.8431 & 53.22 & 67.97 \\
\hline $\mathrm{F}$ & 1.2711 & 13.93 & 28.22 & 0.6270 & 1.40 & 2.22 & 0.8817 & 2.42 & 1.95 \\
\hline $\mathrm{Au}$ & 0.7849 & 67.80 & 13.25 & - & - & - & - & - & - \\
\hline 0 & - & - & - & 1.6934 & 32.86 & 61.67 & 1.9172 & 22.19 & 21.28 \\
\hline $\mathrm{Na}$ & - & - & - & 1.0462 & 0.09 & 0.12 & - & - & - \\
\hline $\mathrm{Si}$ & - & - & - & 1.0092 & 2.10 & 2.24 & 1.0786 & 5.71 & 3.12 \\
\hline $\mathrm{Ca}$ & - & - & - & 1.1011 & 12.15 & 9.11 & 0.8986 & 6.00 & 2.30 \\
\hline $\mathrm{Fe}$ & - & - & - & 0.6018 & 5.50 & 2.95 & 0.6252 & 9.03 & 2.48 \\
\hline $\mathrm{Cu}$ & - & - & - & 0.6452 & 45.90 & 21.69 & - & - & - \\
\hline $\mathrm{Mg}$ & - & - & - & - & - & - & 1.2366 & 1.43 & 0.90 \\
\hline Total & & 100.00 & & & 100.00 & & & 100.00 & \\
\hline
\end{tabular}

\section{References}

[1] Ozkaya B, Akoglu B, Karadag D, Aci G, Taskan E, Hasar E. Bioprocess Biosyst Eng, 2012, 35: 1219

[2] Fernando E, Keshavarz T, Kyazze G. Bioresour Technol, 2013, 127: 1

[3] Lin C W, Wu C H, Huang W T, Tsai S L. Fuel, 2015, 144: 1

[4] Yang G X, Sun Y M, Yuan Z H, Lü P M, Kong X Y, Li L H, Chen G Y, Lu T H. Chin J Catal (杨改秀, 孙永明, 袁振宏, 吕鹏梅, 孔晓英, 李连 华, 陈冠益, 陆天虹. 催化学报), 2014, 35: 770

[5] Kiely P D, Rader G, Regan J M, Logan B E. Bioresour Technol, 2011, 102: 361

[6] He Z, Wagner N, Minteer S D, Angenent L T. Environ Sci Technol, 2006, 40: 5212

[7] Koroglu E O, Yilmaz Baysoy D, Cetinkaya A Y, Ozkaya B, Çakmakci M. Biomass Bioenergy, 2014, 69: 58

[8] Wen Q, Wu Y, Zhao L X, Sun Q. Fuel, 2010, 89: 1381

[9] Venkata Mohan S, Mohanakrishna G, Velvizhi G, Babu V L, Sarma P N. Biochem Eng J, 2010, 51: 32

[10] Zhao F, Harnisch F, Schroder U, Scholz F, Bogdanoff P, Herrmann I.
Environ Sci Technol, 2006, 40: 5193

[11] Kim H J, Park H S, Hyun M S, Chang I S, Kim M, Kim B H. Enzyme Microb Technol, 2002, 30: 145

[12] Koroglu E O, Ozkaya B, Cetinkaya A Y. Int J Energy Sci, 2014, 4: 28

[13] Koroglu E O, Ozkaya B, Denktas C, Cakmakci M. J Biosci Bioeng, 2014, 118: 672

[14] Ghasemi M, Daud W R W, Ismail M, Rahimnejad M, Ismail A F, Leong J X, Miskan M, Ben Liew K. Int J Hydrog Energy, 2013, 38: 5480

[15] Cheng K, He D P, Peng T, Lv H F, Pan M, Mu S C. Electrochim Acta, 2014, 132: 356

[16] Choi T H, Won Y B, Lee J W, Shin D W, Lee Y M, Kim M, Park H B. J Power Sources, 2012, 220: 269

[17] Koskinen P E P, Lay C H, Puhakka J A, Lin P J, Wu S Y, Örlygsson J, Lin C Y. Biotechnol Bioeng, 2008, 101: 665

[18] Koskinen P E P, Kaksonen A H, Puhakka J A. Biotechnol Bioeng, 2007, 97: 742

[19] Behera M, Ghangrekar M M. Bioresour Technol, 2009, 100: 5114

[20] Yates M D, Kiely P D, Call D F, Rismani-Yazdi H, Bibby K, Peccia J, Regan J M, Logan B E. ISME J, 2012, 6: 2002

[21] Jadhav G S, Ghangrekar M M. Bioresour Technol, 2009, 100: 717

\section{Graphical Abstract}

Chin. J. Catal., 2015, 36: 1068-1076 doi: 10.1016/S1872-2067(15)60833-6

Electricity production by a microbial fuel cell fueled by brewery wastewater and the factors in its membrane deterioration

Afșin Y. Çetinkaya*, Emre Oğuz Köroğlu, Neslihan Manav Demir, Derya Yılmaz Baysoy, Bestamin Özkaya, Mehmet Çakmakçı Yildiz Technical University, Turkey; Tampere University of Technology, Finland

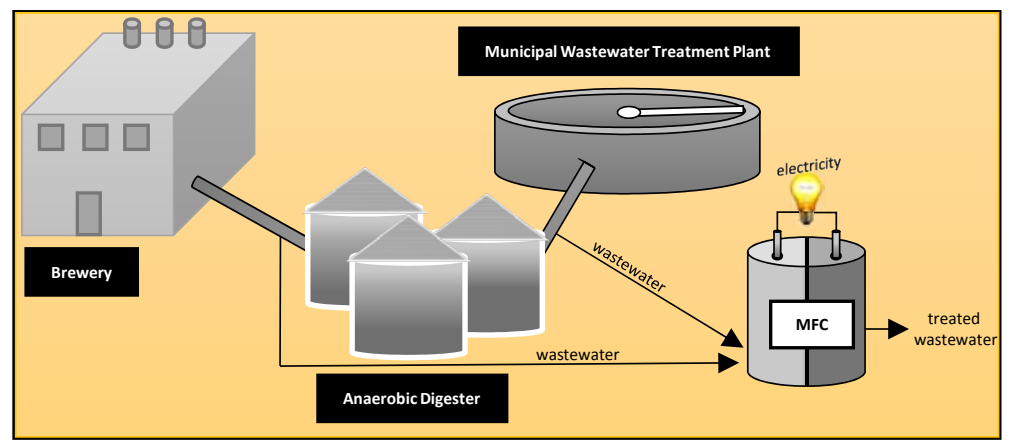

Electricity production by microbial fuel cells (MFCs) using wastewater from a brewing plant and the influence of the hydraulic retention time (HRT) and effect of chemical oxygen demand (COD) removal on MFC performance, the microbial population, surface morphology, and functional groups were investigated. 
[22] Yu J, Park Y, Kim B, Lee T. Bioprocess Biosyst Eng, 2015, 38: 85

[23] Chae K J, Choi M J, Lee J W, Kim K Y, Kim I S. Bioresour Technol, 2009, 100: 3518

[24] Dryden S K, He Z, Ley R E, Angenent L T. Unpublished. http:// getentry.ddbj.nig.ac.jp/getentry/na/EF515697/?filetype=html

[25] Morita M, Malvankar N S, Franks A E, Summers Z M, Giloteaux L, Rotaru A E, Rotaru C, Vargas M, Lovley D R. Unpublished. http:// getentry.ddbj.nig.ac.jp/getentry/na/FR823540/?filetype $=\mathrm{html}$

[26] Uria N, Mas J. Unpublished. http://getentry.ddbj.nig.ac.jp/ getentry/na/HE856389-HE856491/?filetype=html\&limit=100

[27] Zhang X. Unpublished. http://getentry.ddbj.nig.ac.jp/getentry/ na/JQ724353/?filetype $=\mathrm{html}$

[28] Ludvigsson M, Lindgren J, Tegenfeldt J. Electrochim Acta, 2000, 45:
2267

[29] Xu L, Wang J N, Meng Y, Li A M. Chin Chem Lett, 2012, 23: 105

[30] Di Noto V, Piga M, Giffin G A, Lavina S, Smotkin E S, Sanchez J Y, Iojoiu C. J Phys Chem C, 2012, 116: 1370

[31] Wu Y, Guo J, Yang W L, Wang C C, Fu S K. Polymer, 2006, 47: 5287

[32] Danilczuk M, Lin L, Schlick S, Hamrock S J, Schaberg M S. J Power Sources, 2011, 196: 8216

[33] Shin S J, Balabanovich A I, Kim H, Jeong J, Song J, Kim T K. J Power Sources, 2009, 191: 312

[34] Barbora L, Singh R, Shroti N, Verma A. Mater Chem Phys, 2010, 122: 211

[35] Belfer S, Fainchtain R, Purinson Y, Kedem O. J Membr Sci, 2000, 172: 113 